\title{
Regulation of bone growth via ligand-specific activation of estrogen receptor alpha
}

\author{
Maryam Iravani', Marie Lagerquist ${ }^{2}$, Claes Ohlsson² and Lars Sävendahl1 \\ 1Department of Women's and Children's Health, Karolinska Institutet, Stockholm, Sweden \\ ${ }^{2}$ Centre for Bone and Arthritis Research, Institute of Medicine, Sahlgrenska Academy at University of \\ Gothenburg, Gothenburg, Sweden
}

Correspondence should be addressed to M Iravani

Email

Maryam.iravani@ki.se

\begin{abstract}
Estrogens are well known for their capacity to promote bone maturation and at high doses to induce growth plate closure and thereby stop further growth. High-dose estrogen treatment has therefore been used to limit growth in extremely tall girls. However, recent data suggest that this treatment may have severe side effects, including increased risk of cancer and reduced fertility. We hypothesized that estrogenic effects in bone are mediated via ER $\alpha$ signaling. Twelve-week-old ovariectomized female C57BL/6 mice were subcutaneously injected for 4 weeks with E2 or selective ER $\alpha$ (PPT) or ER $\beta$ (DPN) agonists. After killing, tibia and femur lengths were measured, and growth plate morphology was analyzed. E2- and PPT-treated mice had shorter tibiae and femur bones when compared to vehicle-treated controls, whereas animals treated with DPN had similar bone lengths compared to controls. Growth plate height and hypertrophic zone height were reduced in animals treated with E2 or PPT but not in those treated with DPN, supporting that the effect was mediated via ER $\alpha$. Moreover, PCNA staining revealed suppressed proliferation of chondrocytes in the tibia growth plate in PPT- or E2-treated mice compared to controls. Our data show that estrogenic effects on bone growth and growth plate maturation are mainly mediated via ER $\alpha$. Our findings may have direct implications for the development of new and more selective treatment modalities of extreme tall stature using selective estrogen receptor modulators that may have low side effects than high-dose E2 treatment.
\end{abstract}

\section{Key Words \\ - estrogen \\ - estrogen receptor $\alpha$ \\ - growth plate cartilage \\ - bone}

\section{Introduction}

Longitudinal bone growth takes place in the growth plate, consisting of three layers: resting zone, proliferative zone and the hypertrophic zone. Bone growth is regulated by estrogens, acting either indirectly via the GH/IGF-I axis or directly via estrogen receptors (ER) expressed in the growth plate chondrocytes (Borjesson et al. 2013). Multiple studies have shown the importance of estrogens in regulating bone maturation and mineralization and in preventing bone loss. The most effective estrogen is $17 \beta$-estradiol (E2). The importance of $\mathrm{E} 2$ in the regulation of the bone growth is well known. However, the effects of E2 are dose dependent, where low levels stimulate bone growth in early puberty and high levels induce growth plate fusion in late puberty (Juul 2001). In addition to estrogens, phytoestrogens may also affect bone growth and growth plate fusion. Studies performed by our

Published by Bioscientifica Ltd 
group have shown that resveratrol, a phytoestrogen structurally similar to diethylstilbestrol, delayed growth plate fusion and improved longitudinal bone growth in ovariectomized rabbits (Karimian et al. 2013). Moreover, selective estrogen receptor modulators (SERMs) have also been shown to regulate growth plate fusion. Our studies have demonstrated that raloxifene induced growth plate fusion and decreased chondrocyte proliferation in rabbits (Nilsson et al. 2003). In addition, tamoxifen, another SERM, was shown to suppress longitudinal and cortical bone growth in male rats (Karimian et al. 2008).

The expression of ER $\alpha$ and ER $\beta$ in bone and growth plate cartilage has previously been demonstrated (Borjesson et al. 2013). Moreover, gender- and skeletal region-specific variations in ER expression was recently investigated in the rat demonstrating expression of ER $\alpha$ as well as ER $\beta$ in spinal and tibial growth plate chondrocytes in both males and females (Li et al. 2012).

The important role of estrogen signaling in growth plate closure was demonstrated in the studies of patients with aromatase deficiency or an inactivation mutation of the ER $\alpha$ gene (Smith et al. 1994, Morishima et al. 1995, Bilezikian et al. 1998, Quaynor et al. 2013). In addition, a clinical study of an 18-year-old female patient with a homozygous ER $\alpha$ mutation interfering with estrogen signaling has recently suggested that ER $\alpha$ mutations cause estrogen resistance. The symptoms of the patient with a homozygous ER $\alpha$ mutation were similar to the phenotypical changes in the mouse orthologue knockout (Quaynor et al. 2013). In contrast, excessive ER activation, as seen in tall adolescent girls with high doses of estradiol (100-1000 $\mu \mathrm{g} /$ day), leads to premature growth plate closure (Goldzieher 1956, Normann et al. 1991). Unfortunately, high-dose estradiol treatment not only limits further bone growth but also has severe side effects including reduced fertility (Venn et al. 2004, Hendriks et al. 2011) and increased risks of breast and endometrial cancers, as well as melanoma (Collaborative Group 1997, Weiderpass et al. 1999, Benyi et al. 2014). It is important to point out that for contraception much lower doses of estradiol (20-30 $\mu \mathrm{g} /$ day) are nowadays being used (Bachmann \& Kopacz 2009).

Several studies using different mouse models have suggested that ER $\alpha$ is the main ER mediating estrogenic effects in bone (Lindberg et al. 2002, Moverare et al. 2003). In particular, mice with chondrocyte-specific deletion of Esr1-encoding ER $\alpha$ were shown to have longer bones than wild-type mice, suggesting ERo-mediated growth plate fusion (Borjesson et al. 2010). Therefore, estrogen signaling via $\mathrm{ER} \alpha$ has a regulatory effect on longitudinal bone growth and bone development. In contrast to ER $\alpha$, ER $\beta$ was shown only to act in the presence of ER $\alpha$ by moderating its effects in female mouse bone (Sims et al. 2002, Lindberg et al. 2003). Thus, previous studies suggest that ER $\beta$ may affect bone growth mainly in the presence of ER $\alpha$. Based on the current data, we hypothesized that specific ER signaling may have selective effects in growth plate cartilage. To test this, we treated 12-weekold ovariectomized female C57BL/6 mice with $\mathrm{E} 2$ and selective ER $\alpha$ and ER $\beta$ agonists while tibia and femur bone growth was monitored. We aimed to study the effects of selective ER $\alpha$ and ER $\beta$ agonists on longitudinal bone growth.

\section{Materials and methods}

\section{Reagents}

$17 \beta$-estradiol-3-benzoate (E2) was purchased from SigmaAldrich and the ER $\beta$-selective agonist DPN (2,3-bis (4-hydroxyphenyl)propionitrile) and the ER $\alpha$-selective agonist PPT (1,3,5-tris(4-hydroxyphenyl)-4-propyl$1 \mathrm{H}$-pyrazole) were obtained from Tocris Bioscience (Bristol, UK).

Primary rabbit anti-PCNA antibody (RbPAb + PCNAab 18197) was provided by Abcam. Normal donkey serum and secondary CY3-conjugated AffiniPureF (ab) Fragment Donkey Anti-Rabbit IgG antibody were purchased from Jackson ImmunoResearch Laboratories. Fluorescence mounting medium was obtained from Dako. 4',6-diamidino-2-phenylindole dihydrochloride (DAPI) was purchased from Sigma-Aldrich.

\section{Animals}

Twelve-week-old female C57BL/6 mice ( $n=9-10 /$ group) were purchased from Charles River Laboratories. Animals were housed in the animal facility at the University of Gothenburg and kept in 12-h day and night condition with standard chow and tap water ad libitum. The study was approved by the ethical committee for animal experiments at the University of Gothenburg (ethical permit no. 205-2007).

\section{Ovariectomy and treatment}

Mice were randomized into 5 different groups. Four groups were ovariectomized and one group was sham-operated.

Published by Bioscientifica Ltd. 
Both ovariectomy and sham operations were performed at twelve weeks of age under intraperitoneal anesthesia with ketamine (Ketalar; Pfizer) and medetomidine (Domitor; Orion Pharma, Espoo, Finland). Carprofen (Orion Pharma) was used postoperatively for pain relief. A midline incision was followed by flank incisions of the peritoneum, and the ovaries were removed with sterile scissors. The skin incision was closed with metallic clips. The sham-operated mice were treated in the same way, except that the ovaries were not removed. Sham-operated mice were subcutaneously (s.c.) injected with $100 \mu \mathrm{L}$ of vehicle (10\% ethanol and 90\% Miglyol 812, Omya Peralta, Hamburg, Germany) $(n=10)$. The ovariectomized mice were treated s.c. with $100 \mu \mathrm{L}$ of E2 $(1 \mu \mathrm{g} /$ mouse; $0.04 \mathrm{mg} / \mathrm{kg} /$ day) $(n=9)$, PPT ( $175 \mu \mathrm{g} / \mathrm{mouse} ; 7 \mathrm{mg} / \mathrm{kg} /$ day $)$ $(n=10)$, DPN $(105 \mu \mathrm{g} / \mathrm{mouse} ; 4.2 \mathrm{mg} / \mathrm{kg} /$ day $)(n=10)$ or vehicle $(n=10)$. All the groups received injections 5 days per week for 4 weeks.

\section{Tissue samples collection}

The femur and tibia were dissected out and fixed in $4 \%$ phosphate-buffered formalin for $24 \mathrm{~h}$. Decalcification was done in 10\% EDTA for 2 weeks and bones were stored in $70 \%$ ethanol. For histological analysis, tibias were embedded in paraffin. Five micrometer-thick sections were prepared from the paraffin blocks. Uteruses were collected and weighed prior to analysis.

\section{Body weight, uterus, femur and tibia measurements}

Body weight was measured at the beginning and the end of the experiment. Also, at the end of the experiment, mice were killed and uteruses were weighted. The length of the femur and tibia was measured ex vivo using a pocket vernier caliper (Helios-Preisser, Gammertingen, Germany).

\section{Quantitative histology of mouse growth plates}

Tibia growth plates were analyzed ex vivo. For quantitative histology of tibia growth plates, 5 - $\mu$ m-thick paraffinembedded tibia sections were prepared and stained with Alcian blue/van Gieson. The quantitative analysis was performed by measuring two-third of the growth plate sections at $10 \times$ magnification. Images were captured by a Nikon Eclipse E800 light microscope (Nikon) connected to the digital camera (Hamamatsu C4742-95, Hamamatsu City, Japan) with a digital color camera system (Olympus DP70). Olympus MicroImage software (version
4.0; Olympus Optical) was applied for imaging. The height of the whole tibia growth plates was calculated as an average of 20 measurements per growth plate. The height of the proliferative and the hypertrophic zones was measured in 20 columns per tibia growth plates and was presented as an average. Hypertrophic chondrocytes were defined as cells with height bigger than $7 \mu \mathrm{m}$. All the measurements were obtained in a blind manner by Image Pro Plus, version 6.3 software (NIH).

\section{Immunofluorescence/immunocytochemistry for the detection of PCNA expression}

For immunohistochemistry, the tissue sections were deparaffinized for $40 \mathrm{~min}$ at $60^{\circ} \mathrm{C}$, rehydrated in xylene, $100 \%$ ethanol, $95 \%$ ethanol and $75 \%$ ethanol, for $5 \mathrm{~min}$ in each solution and finally washed with water. Antigen retrieval was performed in sodium citrate buffer $(10 \mathrm{mM}$, $\mathrm{pH}$ 6.0) for $15 \mathrm{~min}$ at $95^{\circ} \mathrm{C}$. After retrieval, the slides were incubated with $1.5 \%$ donkey serum in PBS for $1 \mathrm{~h}$ at room temperature (RT), with primary rabbit anti-PCNA antibody (1:250 dilution) overnight at $4^{\circ} \mathrm{C}$ and with secondary donkey anti-rabbit antibody (1:250 dilution) for $1 \mathrm{~h}$ at RT. Nuclear staining with DAPI was performed for $15 \mathrm{~min}$ at RT. After the staining, the slides were mounted with Dako Fluorescence Mounting Medium.

\section{TUNEL assay (apoptosis detection)}

The TUNEL assay was performed according to the manufacturer's instructions. Briefly, apoptotic chondrocytes were identified by terminal deoxynucleotidyltransferase (TdT)-mediated deoxyUTP nick end labeling (TUNEL) immunohistochemistry applying the TdT-FragEL DNA fragmentation kit (Oncogene Research, Boston, MA, USA) as described previously by our group (Chagin et al. 2004). Alexa-546 (Invitrogen) (red florescence) positive cells represented apoptotic chondrocytes.

\section{Statistical analysis}

All the data are shown as mean \pm s.e.m., and the differences between control and treated groups were calculated by one-way ANOVA by multiple comparisons vs control group (Holm-Sidak method). ${ }^{* * *} P<0.001$, ${ }^{*} P<0.01$ and ${ }^{*} P<0.05$ were considered as statistically significant.
๑) 2017 Society for Endocrinology Printed in Great Britain 
A

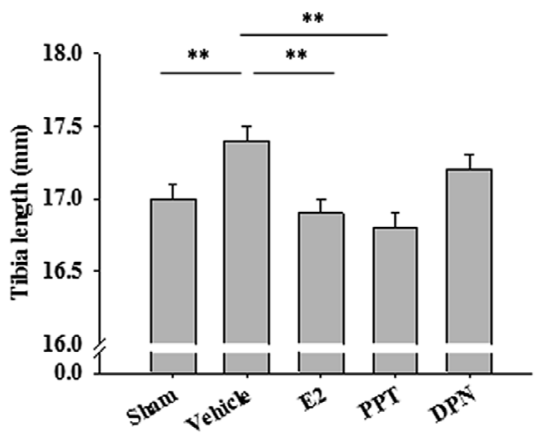

B

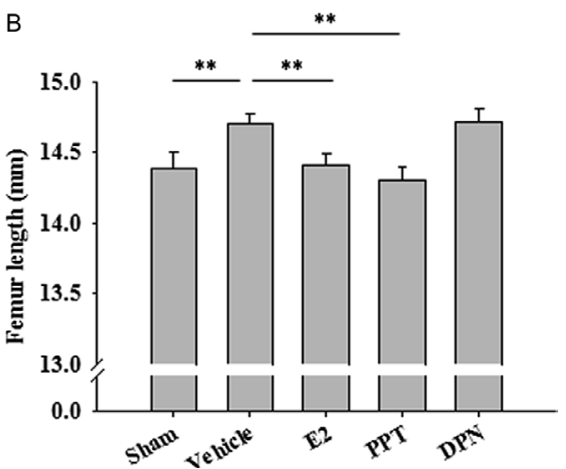

Figure 1

Effects of E2 and ER $\alpha$ and ER $\beta$ agonists on tibia and femur length. The study groups included ovariectomized mice treated with E2, ER $\alpha$ agonist PPT, ER $\beta$ agonist DPN or vehicle alone and sham-operated mice. The group treated with E2 consisted of 9 mice, the other treatment groups contained 10 mice each. Values are means \pm S.E.M. $* P<0.05$ and $* * P<0.01$. Tibia length $(A)$ and femur length (B).

\section{Results}

Effects of E2 and selective ER $\alpha$ and ER $\beta$ agonists on tibia and femur growth

To analyze the effects of E2 and selective ER $\alpha$ and ER $\beta$ agonists, mice were ovariectomized and treated with E2, PPT or DPN. Tibia and femur longitudinal growth was decreased by either E2 or PPT treatment compared to vehicle (Fig. $1 \mathrm{~A}$ and $\mathrm{B} ; P<0.01$ ). However, DPN did not have any effect (Fig. 1A and B). Longitudinal growth of tibia and femur was decreased in sham-operated mice with intact ovaries compared to OVX vehicle (Fig. 1A and $\mathrm{B} ; P<0.01)$.

\section{Effects of E2 and selective ER $\alpha$ and ER $\beta$ agonists on tibia growth plate cartilage}

Histological evaluation of tibia sections was performed to investigate the effects of $\mathrm{E} 2$ and selective ER $\alpha$ and ER $\beta$ agonists on the growth plate. In OVX mice, the growth plate height was decreased by E2 or PPT treatment compared to vehicle (Fig. 2A and B; $P<0.001$ ), whereas DPN had no effect on growth plate height. In addition, the growth plate height was also decreased in shamoperated mice compared to vehicle-treated OVX mice (Fig. 2A and B; $P<0.001$ ).

Additional histological analysis of tibia growth plate zones in OVX mice showed that the height of both proliferative and hypertrophic zones was decreased by E2 or PPT treatment compared to vehicle (Fig. 2C and D; $P<0.01)$. However, no effect was detected on DPN treatment. In addition, the height of both proliferative and hypertrophic zones was also decreased in shamoperated mice compared to OVX vehicle (Fig. 2C and D; $P<0.001)$.

Interestingly, the hypertrophic zone was more affected than the proliferative zone by either E2 or PPT treatment.
As a consequence, the proliferative/hypertrophic ratio observed was higher in mice treated with either E2 or PPT than in other treatment groups (Fig. 2E; $P<0.001$ ).

\section{Effects of E2 and selective $E R \alpha$ and $E R \beta$ agonists on chondrocyte proliferation and apoptosis}

The effects of E2 and selective ER $\alpha$ and ER $\beta$ agonists on the proliferation capacity of growth plate chondrocytes were analyzed by PCNA staining. The histological evaluation of PCNA staining of tibia growth plate cartilage showed lower proliferation in E2- or PPT-treated OVX mice compared to OVX vehicle (Fig. 3A; $P<0.001$; Supplementary Fig. 1, see section on supplementary data given at the end of this article). However, proliferation was not affected by DPN treatment. Besides, proliferation in tibia growth plate cartilage was also decreased in shamoperated mice compared to vehicle-treated OVX mice (Fig. 3A; $P<0.001$ ). In addition, the effects of $\mathrm{E} 2$ and selective ER $\alpha$ and ER $\beta$ agonists on apoptosis were studied by TUNEL assay. No significant differences in apoptosis level were detected between the different treatment groups (Fig. 3B).

\section{Effects of E2 and selective $E R \alpha$ and $\operatorname{ER} \beta$ agonists on body and uterus weights}

Treatments with E2 or selective ER $\alpha$ and ER $\beta$ agonists did not have any effect on body weight. However, body weight was decreased in sham-operated mice compared to OVX vehicle (Table $1 ; P<0.001$ ). With regard to the effects on uterus weight, treatments with either E2 or PPT increased uterus weight in OVX mice (Table $1 ; P<0.001$ ). However, uterus weight was not affected by DPN treatment in OVX mice (Table 1). As expected, uterus weight was increased in sham-operated mice when compared to vehicle-treated OVX mice (Table $1 ; P<0.001$ ). 
A
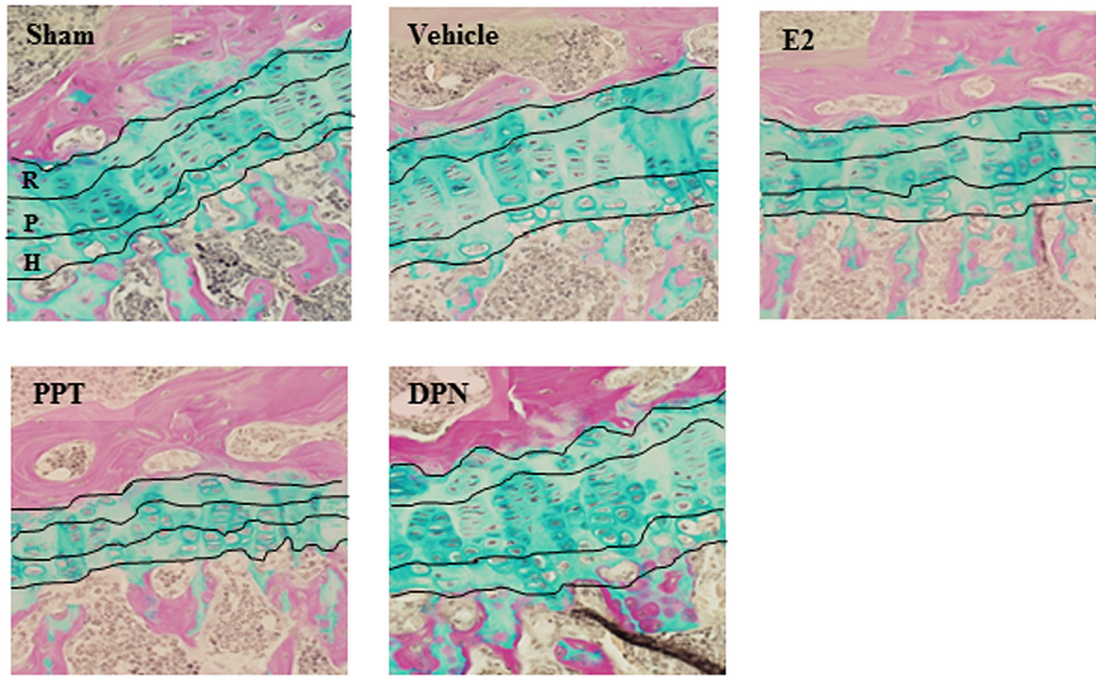

B

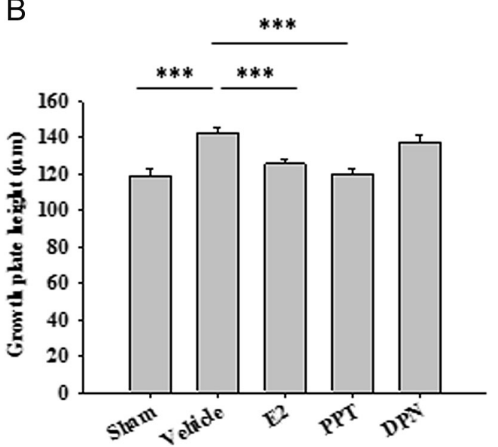

D

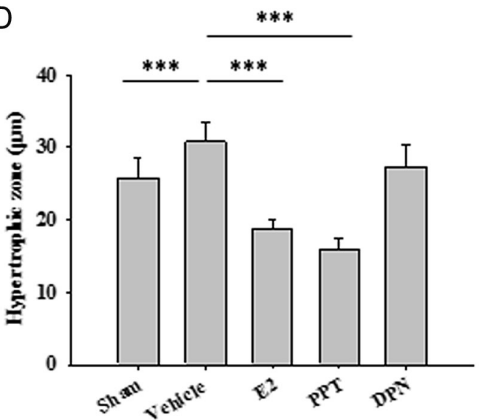

\section{Discussion}

We here show that selective ER $\alpha$ agonist PPT or E2 treatment decreased tibia and femur longitudinal growth in female OVX mice. In addition, the height of the tibia growth plate cartilage was decreased by PPT or E2 treatments. These changes were observed in both the proliferative and the hypertrophic zones of the tibia growth plate. Similar findings in the group of animals treated with $\mathrm{E} 2$ and $\mathrm{ER} \alpha$ agonist, but not with $\mathrm{ER} \beta$ agonist,
C

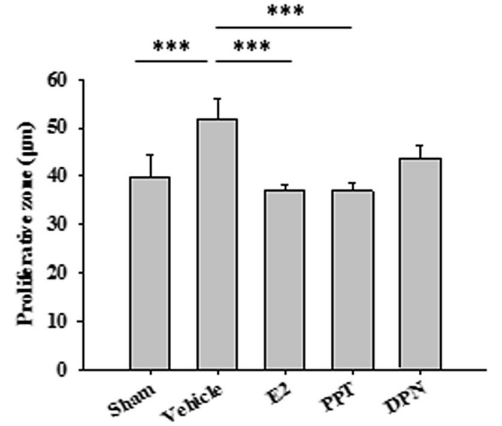

E

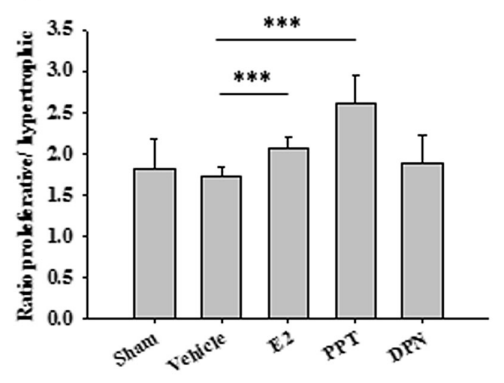

Figure 2

Effects of $E 2$ and $E R \alpha$ and $E R \beta$ agonists on tibia growth plate length and proliferative and hypertrophic chondrocytes. Alcian blue/van Gieson staining of mouse proximal tibia growth plate. $\mathrm{R}=$ resting zone; $\mathrm{P}=$ proliferative zone and $\mathrm{H}=$ hypertrophic zone (A), quantitative morphological studies showing the total growth plate height. (B), the height of the proliferative zone (C), the height of the hypertrophic zone (D) and ratios of proliferative/hypertrophic zones (E). Magnifications 10x. The group treated with E2 consisted of 9 mice, and the other treatment groups contained 10 mice each. Values are means \pm s.E.M., $* * * P<0.001$. suggest that the observed effects of E2 are mediated via ER $\alpha$.

With regard to ER $\alpha$-mediated regulation of bone growth, ER $\alpha$-expressing growth plate chondrocytes are potential targets for ER $\alpha$-selective agonists. Moreover, ER $\alpha$ was shown to be a regulator of chondrocyte proliferation mediating longitudinal bone growth using a transgenic mouse model (Ikeda et al. 2012). Our findings are in line with previous studies in global and chondrocyte-specific $\mathrm{ER} \alpha$ knockout models demonstrating inhibitory effect 
A

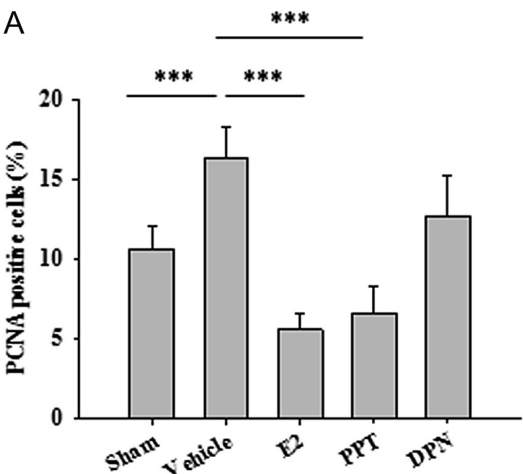

B

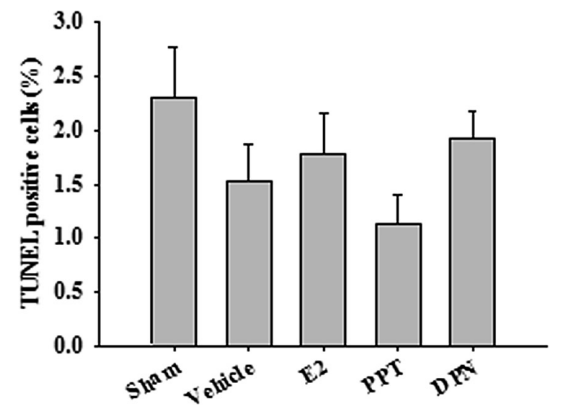

Figure 3

Proliferation and apoptotic detection in tibia growth plate chondrocytes. The effects of E2 and selective $E R \alpha$ and $E R \beta$ agonists on chondrocyte proliferation and apoptosis were analyzed by the PCNA (A) and TUNEL (B) techniques, and percentages of positive cells were calculated. The group treated with E2 consisted of 9 mice, and the other treatment groups contained 10 mice each. Values are means \pm S.E.M. ${ }^{* *} P<0.001$. of ER $\alpha$ on bone growth (Borjesson et al. 2010, 2012). In addition, the expression of constitutively active mutant ER $\alpha$ in chondrocytes was shown to reduce chondrocyte proliferation and impair longitudinal bone growth in female mice (Ikeda et al. 2012). Our study is the first to demonstrate that ligand-dependent activation of ER $\alpha$ causes suppression of bone growth. We have shown that E2 and PPT treatments negatively affect the height of both proliferative and hypertrophic zones. Both hypertrophic and prehypertrophic chondrocytes were shown to be decreased in a mouse model expressing constitutively active mutant ERo in chondrocytes (Ikeda et al. 2012).

In contrast to the selective ER $\alpha$ agonist (PPT), the selective ER $\beta$ agonist (DPN) did not show any effect on longitudinal bone growth or growth plate chondrocytes proliferation. Previous studies showed regulation of skeletal growth by ER $\beta$ in female (Lindberg et al. 2001) but not in male mice (Vidal et al. 2000). Furthermore, a recent in vitro study suggested an inhibitory effect of ER $\beta$ on chondrocyte proliferation (Zeng et al. 2016). Taking all this into account, it is still possible that ER $\beta$ activation may have an effect on bone growth.

With regard to the effects on proliferation, mechanistic studies of growth plate cartilage revealed suppressed proliferation of chondrocytes by PPT or E2 in the tibia growth plate. In contrast, the histological analysis showed no effects on apoptosis in all treatment groups, although

Table 1 Body and uterus weights of female mice treated with $\mathrm{E} 2$ or selective $\mathrm{ER} \alpha$ and $\mathrm{ER} \beta$ agonists.

\begin{tabular}{|c|c|c|}
\hline & Body weight (g) & Uterus weight (mg) \\
\hline Sham $(n=10)$ & $19.5 \pm 0.4 * * *$ & $33.1 \pm 4.2 * * *$ \\
\hline Vehicle $(n=10)$ & $21.3 \pm 0.2$ & $15.1 \pm 1.4$ \\
\hline $\mathrm{E} 2(n=9)$ & $21.1 \pm 0.3$ & $106.3 \pm 7.8 * * *$ \\
\hline PPT $(n=10)$ & $20.9 \pm 0.3$ & $26.4 \pm 1.7 * * *$ \\
\hline DPN $(n=10)$ & $21.7 \pm 0.3$ & $12.2 \pm 1.1$ \\
\hline
\end{tabular}

$* * * P<0.001$ vs vehicle. genes involved in apoptosis were previously found to be regulated by ER $\alpha$ in bone (Chokalingam et al. 2012). In line with our data, a recent study found no differences in apoptosis between $\mathrm{ER}^{-/-}$and WT mice (Borjesson et al. 2012). However, molecular mechanisms of ER $\alpha$-mediated bone growth inhibition remain to be identified. Gene expression analysis, such as RNA sequencing, could be applied to identify the spectrum of target genes regulated via ERo in the growth plate.

Previous studies have found different effects of estradiol on growth plate closure in humans and mice. High doses of estradiol induce growth plate closure in humans but not in mice at the end of puberty (Weise et al. 2001). Therefore, care should be taken in extrapolating these findings in mice to humans. With regard to clinical applications of our findings, toxicological studies must be performed to evaluate the potential adverse effects of selective ER $\alpha$ agonists. In particular, ligand-dependent ER $\alpha$ activation may induce tumorigenic side effects, especially in women, as ERo has been implicated in the progression of breast cancer (Cortez et al. 2010). Furthermore, a study of male ER $\alpha$ knock-in mice treated with PPT showed that ER $\alpha$ signaling is important for male mouse reproductive tract development (Sinkevicius et al. 2009).

Studies of PPT activity in estrogen target tissue in vivo showed that PPT was as effective in stimulating uterine weight as E2; however, it required higher concentration than $\mathrm{E} 2$ to achieve the stimulating effect (Harris et al. 2002). In contrast with these observations, in our study, PPT inhibited bone growth, but had very weak uterotrophic effect compared to E2. These results suggest that it may be possible to optimize doses of PPT to suppress growth plate proliferation, without substantially affecting uterus and mammary glands. Currently, a limited number of studies used selective ER $\alpha$ agonists in vivo (Arias-Loza et al. 2008), and further experiments are still needed to determine the potential side effects of PPT and other ER $\alpha$ agonists. 
To conclude, we here demonstrate that a selective $\mathrm{ER} \alpha$ agonist has the capacity to suppress longitudinal bone growth in treated mice. Our findings may have direct implications for the development of a specific treatment of extreme tall stature.

\section{Supplementary data}

This is linked to the online version of the paper at http://dx.doi.org/10.1530/ JOE-16-0263.

\section{Declaration of interest}

The authors declare that there is no conflict of interest that could be perceived as prejudicing the impartiality of the research reported.

\section{Funding}

This study was supported by Stockholm City Council, Swedish Research Council, Pfizer Inc and a grant from Karolinska Institutet.

\section{Authors' contribution statement}

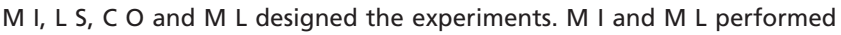
the experiments. Data were analyzed by M I and M L. M I drafted the manuscript. Critical review of the manuscript was done by $L S, C O$ and $M$ L. Final version was approved by L S, M I, C O and M L.

\section{Acknowledgments}

The authors thank Dr Emma Ericsson for helping with the software's introduction at the beginning of the project.

\section{References}

Arias-Loza PA, Jazbutyte V \& Pelzer T 2008 Genetic and pharmacologic strategies to determine the function of estrogen receptor alpha and estrogen receptor beta in cardiovascular system. Gender Medicine 5 (Supplement A) S34-S45. (doi:10.1016/j.genm.2008.03.005)

Bachmann G \& Kopacz S 2009 Drospirenone/ethinyl estradiol 3 mg/20 mug (24/4 day regimen): hormonal contraceptive choices - use of a fourth-generation progestin. Patient Preference and Adherence $\mathbf{3}$ 259-264. (doi:10.2147/PPA.S3901)

Benyi E, Kieler H, Linder M, Ritzen M, Carlstedt-Duke J, Tuvemo T, Westphal O \& Savendahl L 2014 Risks of malignant and nonmalignant tumours in tall women treated with high-dose oestrogen during adolescence. Hormone Research in Paediatrics 82 89-96. (doi:10.1159/000360137)

Bilezikian JP, Morishima A, Bell J \& Grumbach MM 1998 Increased bone mass as a result of estrogen therapy in a man with aromatase deficiency. New England Journal of Medicine 339 599-603. (doi:10.1056/NEJM199808273390905)

Borjesson AE, Lagerquist MK, Liu C, Shao R, Windahl SH, Karlsson C, Sjogren K, Moverare-Skrtic S, Antal MC, Krust A, et al. 2010 The role of estrogen receptor alpha in growth plate cartilage for longitudinal bone growth. Journal of Bone and Mineral Research 25 2690-2700. (doi:10.1002/jbmr.156)

Borjesson AE, Windahl SH, Karimian E, Eriksson EE, Lagerquist MK, Engdahl C, Antal MC, Krust A, Chambon P, Savendahl L, et al. 2012 The role of estrogen receptor-alpha and its activation function- 1 for growth plate closure in female mice. American Journal of Physiology: Endocrinology and Metabolism 302 E1381-E1389. (doi:10.1152/ ajpendo.00646.2011)

Borjesson AE, Lagerquist MK, Windahl SH \& Ohlsson C 2013 The role of estrogen receptor alpha in the regulation of bone and growth plate cartilage. Cellular and Molecular Life Sciences 70 4023-4037. (doi:10.1007/s00018-013-1317-1)

Chagin AS, Lindberg MK, Andersson N, Moverare S, Gustafsson JA, Savendahl L \& Ohlsson C 2004 Estrogen receptor-beta inhibits skeletal growth and has the capacity to mediate growth plate fusion in female mice. Journal of Bone and Mineral Research 19 72-77. (doi:10.1359/jbmr.0301203)

Chokalingam K, Roforth MM, Nicks KM, McGregor U, Fraser D, Khosla S \& Monroe DG 2012 Examination of ERalpha signaling pathways in bone of mutant mouse models reveals the importance of EREdependent signaling. Endocrinology 153 5325-5333. (doi:10.1210/ en.2012-1721)

Collaborative Group on Hormonal Factors in Breast Cancer 1997 Breast cancer and hormone replacement therapy: collaborative reanalysis of data from 51 epidemiological studies of 52,705 women with breast cancer and 108,411 women without breast cancer. Lancet 350 1047-1059. (doi:10.1016/s0140-6736(97)08233-0)

Cortez V, Mann M, Brann DW \& Vadlamudi RK 2010 Extranuclear signaling by estrogen: role in breast cancer progression and metastasis. Minerva Ginecologica 62 573-583.

Goldzieher MA 1956 Treatment of excessive growth in the adolescent female. Journal of Clinical Endocrinology and Metabolism 16 249-252. (doi:10.1210/jcem-16-2-249)

Harris HA, Katzenellenbogen JA \& Katzenellenbogen BS 2002 Characterization of the biological roles of the estrogen receptors, ERalpha and ERbeta, in estrogen target tissues in vivo through the use of an ERalpha-selective ligand. Endocrinology 143 4172-4177. (doi:10.1210/en.2002-220403)

Hendriks AE, Laven JS, Valkenburg O, Fong SL, Fauser BC, de Ridder MA, de Jong FH, Visser JA, van Ginneken AM, Boot AM, et al. 2011 Fertility and ovarian function in high-dose estrogen-treated tall women. Journal of Clinical Endocrinology and Metabolism 96 1098-1105. (doi:10.1210/jc.2010-2244)

Ikeda K, Tsukui T, Imazawa Y, Horie-Inoue K \& Inoue S 2012 Conditional expression of constitutively active estrogen receptor alpha in chondrocytes impairs longitudinal bone growth in mice. Biochemical and Biophysical Research Communications 425 912-917. (doi:10.1016/j. bbrc.2012.07.170)

Juul A 2001 The effects of oestrogens on linear bone growth. Human Reproduction Update 7 303-313. (doi:10.1093/humupd/7.3.303)

Karimian E, Chagin AS, Gjerde J, Heino T, Lien EA, Ohlsson C \& Savendahl L 2008 Tamoxifen impairs both longitudinal and cortical bone growth in young male rats. Journal of Bone and Mineral Research 23 1267-1277. (doi:10.1359/jbmr.080319)

Karimian E, Tamm C, Chagin AS, Samuelsson K, Kjartansdottir KR, Ohlsson C \& Savendahl L 2013 Resveratrol treatment delays growth plate fusion and improves bone growth in female rabbits. PLOS ONE $\mathbf{8}$ e67859. (doi:10.1371/journal.pone.0067859)

Li XF, Wang SJ, Jiang LS \& Dai LY 2012 Gender- and region-specific variations of estrogen receptor alpha and beta expression in the growth plate of spine and limb during development and adulthood. Histochemistry and Cell Biology 137 79-95. (doi:10.1007/s00418-011-0877-0)

Lindberg MK, Alatalo SL, Halleen JM, Mohan S, Gustafsson JA \& Ohlsson C 2001 Estrogen receptor specificity in the regulation of the skeleton in female mice. Journal of Endocrinology 171 229-236. (doi:10.1677/joe.0.1710229) 
Lindberg MK, Weihua Z, Andersson N, Moverare S, Gao H, Vidal O, Erlandsson M, Windahl S, Andersson G, Lubahn DB, et al. 2002 Estrogen receptor specificity for the effects of estrogen in ovariectomized mice. Journal of Endocrinology 174 167-178. (doi:10.1677/joe.0.1740167)

Lindberg MK, Moverare S, Skrtic S, Gao H, Dahlman-Wright K, Gustafsson JA \& Ohlsson C 2003 Estrogen receptor (ER)-beta reduces ERalpha-regulated gene transcription, supporting a 'ying yang' relationship between ERalpha and ERbeta in mice. Molecular Endocrinology 17 203-208. (doi:10.1210/me.2002-0206)

Morishima A, Grumbach MM, Simpson ER, Fisher C \& Qin K 1995 Aromatase deficiency in male and female siblings caused by a novel mutation and the physiological role of estrogens. Journal of Clinical Endocrinology and Metabolism 80 3689-3698. (doi:10.1210/ jcem.80.12.8530621)

Moverare S, Venken K, Eriksson AL, Andersson N, Skrtic S, Wergedal J, Mohan S, Salmon P, Bouillon R, Gustafsson JA, et al. 2003 Differential effects on bone of estrogen receptor alpha and androgen receptor activation in orchidectomized adult male mice. PNAS $\mathbf{1 0 0}$ 13573-13578. (doi:10.1073/pnas.2233084100)

Nilsson O, Falk J, Ritzen EM, Baron J \& Savendahl L 2003 Raloxifene acts as an estrogen agonist on the rabbit growth plate. Endocrinology 144 1481-1485. (doi:10.1210/en.2002-221108)

Normann EK, Trygstad O, Larsen S \& Dahl-Jorgensen K 1991 Height reduction in 539 tall girls treated with three different dosages of ethinyloestradiol. Archives of Disease in Childhood 66 1275-1278. (doi:10.1136/adc.66.11.1275)

Quaynor SD, Stradtman EW Jr, Kim HG, Shen Y, Chorich LP, Schreihofer DA \& Layman LC 2013 Delayed puberty and estrogen resistance in a woman with estrogen receptor alpha variant. New England Journal of Medicine 369 164-171. (doi:10.1056/NEJMoa1303611)
Sims NA, Dupont S, Krust A, Clement-Lacroix P, Minet D, Resche-Rigon M, Gaillard-Kelly M \& Baron R 2002 Deletion of estrogen receptors reveals a regulatory role for estrogen receptorsbeta in bone remodeling in females but not in males. Bone 30 18-25. (doi:10.1016/S8756-3282(01)00643-3)

Sinkevicius KW, Laine M, Lotan TL, Woloszyn K, Richburg JH \& Greene GL 2009 Estrogen-dependent and -independent estrogen receptor-alpha signaling separately regulate male fertility. Endocrinology 150 2898-2905. (doi:10.1210/en.2008-1016)

Smith EP, Boyd J, Frank GR, Takahashi H, Cohen RM, Specker B, Williams TC, Lubahn DB \& Korach KS 1994 Estrogen resistance caused by a mutation in the estrogen-receptor gene in a man. New England Journal of Medicine 331 1056-1061. (doi:10.1056/NEJM199410203311604)

Venn A, Bruinsma F, Werther G, Pyett P, Baird D, Jones P, Rayner J \& Lumley J 2004 Oestrogen treatment to reduce the adult height of tall girls: long-term effects on fertility. Lancet 364 1513-1518. (doi:10.1016/S0140-6736(04)17274-7)

Vidal O, Lindberg MK, Hollberg K, Baylink DJ, Andersson G, Lubahn DB, Mohan S, Gustafsson JA \& Ohlsson C 2000 Estrogen receptor specificity in the regulation of skeletal growth and maturation in male mice. PNAS 97 5474-5479. (doi:10.1073/pnas.97.10.5474)

Weiderpass E, Baron JA, Adami HO, Magnusson C, Lindgren A, Bergstrom R, Correia N \& Persson I 1999 Low-potency oestrogen and risk of endometrial cancer: a case-control study. Lancet $\mathbf{3 5 3}$ 1824-1828. (doi:10.1016/S0140-6736(98)10233-7)

Weise M, De-Levi S, Barnes KM, Gafni RI, Abad V \& Baron J 2001 Effects of estrogen on growth plate senescence and epiphyseal fusion. PNAS 98 6871-6876. (doi:10.1073/pnas.121180498)

Zeng K, Zhang HQ, Chen Y \& Gao Q 2016 Estradiol via estrogen receptor beta inhibits chondrogenesis of mouse vertebral growth plate in vitro. Child's Nervous System 32 461-465. (doi:10.1007/s00381-015-2973-2)

Received in final form 12 December 2016

Accepted 20 December 2016

Accepted Preprint published online 20 December 2016 (c) 2017 Society for Endocrinology Printed in Great Britain 